\title{
THE OCCURRENCE OF RARE EARTH ELEMENTS IN SOME FINNISH MIRES
}

\author{
INKERI YLIRUOKANEN and SARI LEHTO
}

YLIRUOKANEN, INKERI and LEHTO, SARI 1995. The occurrence of rare earth elements in some Finnish mires. Bull. Geol. Soc. Finland 67, Part II, 2738.

The content of the more abundant rare earths (RE) (Y, La, Ce, Pr, Nd and Sm) in the ash of 399 peat samples from 26 Finnish mires was determined by X-ray fluorescence spectrometry. The content of all rare earths ( $\mathrm{La}-\mathrm{Lu}, \mathrm{Y}$ ) in 29 samples was also determined by spark source mass spectrometry. The median RE contents in peat ashes from areas where the bedrock consists of rapakivi granite, granite or archean gneiss are reported. Detailed data concerning the individual mires are also presented. The highest RE contents were found in samples from rapakivi granite areas where a strong negative Eu anomaly was also observed. The RE contents were in general highest at the basal peat layers.

Key words: bogs, peat, rare earths, X-ray fluorescence, mass spectroscopy, granites, gneisses, Finland.

Inkeri Yliruokanen and Sari Lehto: Laboratory of Inorganic and Analytical Chemistry, Helsinki University of Technology, FIN-02150 Espoo, Finland

\section{INTRODUCTION}

The rare earth contents in various geochemical and biogeochemical samples have been extensively studied because of their diagnostic importance in geochemistry (Henderson 1984, Taylor \& McLennan 1988). The occurrence of rare earth elements in peat, however, has not received such a wide interest. Only some of them are normally included in investigations dealing with trace element contents in peats (Virtanen 1993, Markert \& Thornton 1990, Read \& Hooker 1989).

During the period of 1974-77 a large number of peat samples were collected from the Finnish 
mires and their trace element contents were investigated (Minkkinen \& Yliruokanen 1978, Yliruokanen 1980a, Yliruokanen 1980b, Yliruokanen 1981). In this paper we present some results of rare earth contents of peat samples which were collected from areas where the bedrock consists of rapakivi granite, granite, or archean gneiss. Fig. 1 shows the locations of the sampled mires on the geological map of Finland. The density of sampling was $1-2 \mathrm{sites} / \mathrm{km}^{2}$. At each site a vertical profile was sampled, starting from the bottom of the mire. Samples were taken with a Hiller sampler $(50 \mathrm{~cm} \times 2.5 \mathrm{~cm}$ tube) at onemeter intervals (Minkkinen \& Yliruokanen 1978).
$\mathrm{X}$-ray fluorescence $(\mathrm{XRF})$ spectrometry was used for the determination of $\mathrm{Y}, \mathrm{La}, \mathrm{Ce}, \mathrm{Pr}, \mathrm{Nd}$ and $\mathrm{Sm}$ contents in the ash of 399 peat samples from 26 mires. 29 samples were measured by spark source mass spectrometry (SSMS) by which the contents $\mathrm{Eu}, \mathrm{Gd}, \mathrm{Tb}, \mathrm{Dy}, \mathrm{Ho}, \mathrm{Er}, \mathrm{Tm}, \mathrm{Yb}$ and Lu were also obtained.

\section{EXPERIMENTAL}

The peat samples were ashed in $550{ }^{\circ} \mathrm{C}$. The analytical samples for XRF spectrometry were prepared by pressing $40 \mathrm{mg}$ of peat ash onto a filter-

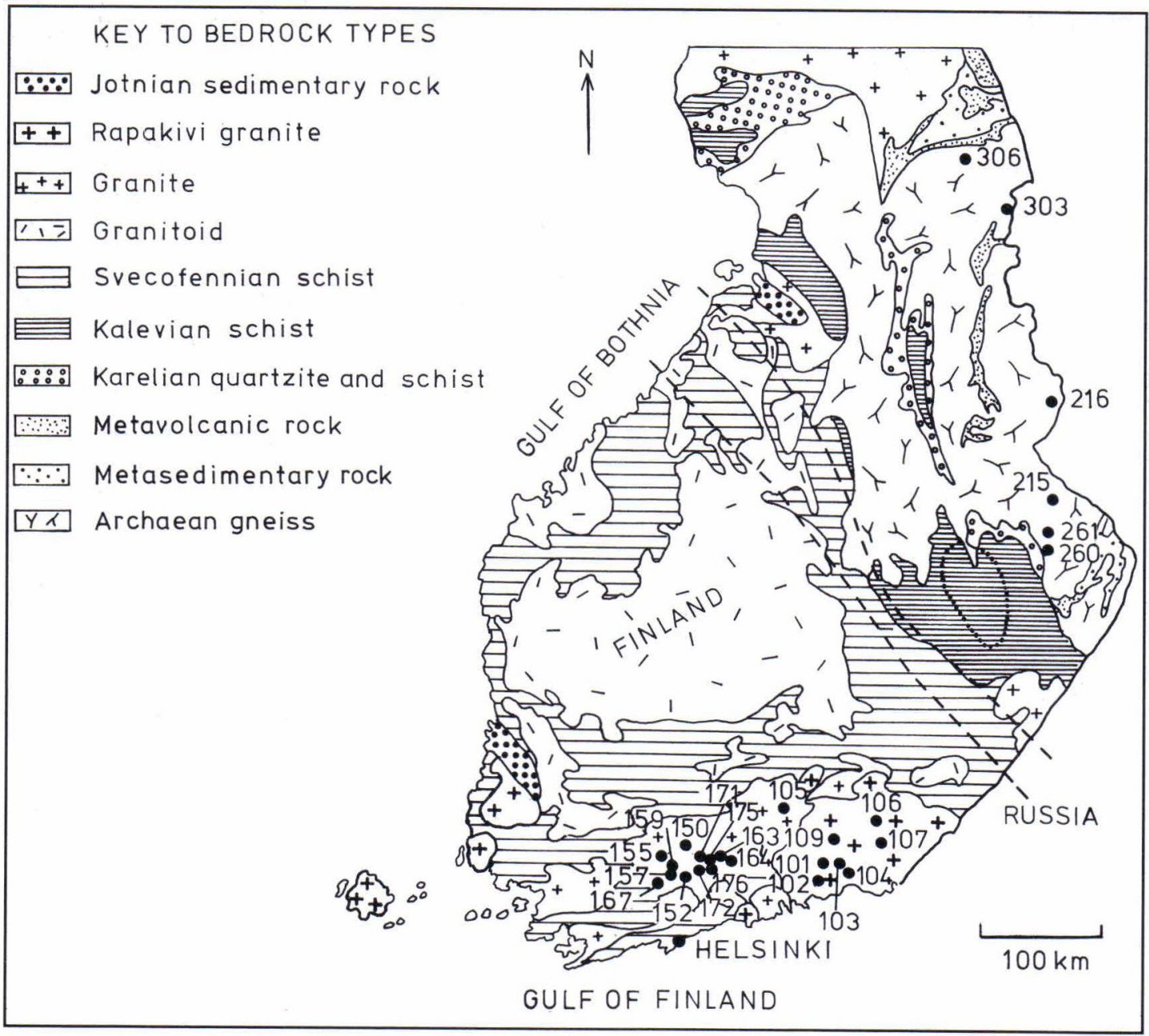

Figure 1. The bedrock map of southern and central Finland and locations of the mires sampled. 
paper support. Calibration standards were prepared by mixing $0.5 \%$ Rare Earth L Standard (Spex Industries, Inc.) with three different types of synthetic peat ash with compositions that are shown in Table 1.

Table 1. Compositions of the synthetic peat ashes used in the XRF analyses.

\begin{tabular}{|l|c|c|c|}
\hline \multirow{2}{*}{ reagents } & \multicolumn{3}{|c|}{ composition (\%) } \\
\cline { 2 - 4 } & 1 & 2 & 3 \\
\hline $\mathrm{SiO}_{2}{ }^{\mathrm{a}}$ & 47.55 & 47.50 & 69.31 \\
\hline $\mathrm{Fe}_{2} \mathrm{O}_{3}{ }^{\mathrm{b}}$ & 17.30 & 8.60 & 1.98 \\
\hline $\mathrm{CaCO}_{3}{ }^{\mathrm{b}}$ & 30.90 & 30.90 & 11.88 \\
\hline $\mathrm{Na}_{2} \mathrm{SO}_{4}$ & 1.90 & 4.30 & - \\
\hline $\mathrm{KPO}_{3}{ }^{\mathrm{c}}$ & 1.90 & 3.4 & 3.27 \\
\hline $\mathrm{TiO}_{2}{ }^{\mathrm{a}}$ & 0.45 & 1.7 & 0.69 \\
\hline $\mathrm{Al}_{2} \mathrm{O}_{3}{ }^{\mathrm{a}}$ & - & 5.00 & 5.94 \\
\hline $\mathrm{K}_{2} \mathrm{SO}_{4}{ }^{\mathrm{c}}$ & - & - & 3.96 \\
\hline $\mathrm{NaCl}^{\mathrm{d}}$ & - & - & 2.97 \\
\hline
\end{tabular}

${ }^{\text {a }}$ Spex

${ }^{\mathrm{b}}$ Merck, p.a.

${ }^{\mathrm{c}}$ Sp.K.

${ }^{\mathrm{d}}$ Merck, suprapur

XRF intensities were measured by a wavelength dispersive Philips PW1480 spectrometer with an $\mathrm{X}$-ray tube having an Sc-Mo dual anode. For Y $K_{\alpha}$ fluorescent emission was measured, $L_{\alpha}$ for $\mathrm{La}, \mathrm{Nd}$ and Sm and $L_{\beta}$ for Ce and Pr. For the excitation of Y $K_{\alpha}$ radiation the X-ray tube was operated at 80 $\mathrm{kV}$ and $30 \mathrm{~mA}$ and for the excitation of the $L$-lines $60 \mathrm{kV}$ and $50 \mathrm{~mA}$ were used. The analyser crystal was $\operatorname{LiF}(220)$ and the measuring time was $60 \mathrm{~s}$. Scintillation detector was used for $\mathrm{Y} K_{\alpha}$ and a flow proportional counter for the $L$-lines. Background signal for Sm was measured on one side only.

Calibration curves for each rare earth element were compiled. Correlation factors for the different elements ranged from 0.973-0.998. Detection limits obtained by the $3 \sigma$ criterion were $20 \mathrm{ppm}$ for $\mathrm{Y}$ and $\mathrm{La}, 50 \mathrm{ppm}$ for $\mathrm{Ce}$, and $35 \mathrm{ppm}$ for $\mathrm{Pr}, \mathrm{Nd}$ and $\mathrm{Sm}$. The $3 \sigma$ values were determined from the signals measured for 8 different synthetic peat ashes without lanthanoid doping. The rather high detection limits are a result of the small sample size which again has been a necessity considering the amount of samples taken.

The SSMS analyses were performed by an A.E.I. double-focusing mass spectrograph MS702 with $r f$ spark and electrical detection (Nieminen \& Yliruokanen 1974). Samples were mixed with an equal weight of Ringsdorff RW-A graphite powder and compressed to electrodes. Standards containing 50 or $250 \mathrm{ppm}$ of each rare earth element in a synthetic plant ash were applied (Lounamaa 1956). Rhenium was used as an internal standard.

Correlation between results obtained by the two methods mentioned above was good. Correlation coefficients for the different rare earth elements ranged from 0.980 to 0.997 .

\section{RESULTS AND DISCUSSION}

The bedrock on the sampling sites consists of either rapakivi granite, granite or archean gneiss. The median contents and ranges of $\mathrm{Y}, \mathrm{La}, \mathrm{Ce}, \mathrm{Pr}$, $\mathrm{Nd}$ and $\mathrm{Sm}$ in peat ashes from these areas are arranged accordingly in Table 2 . The data presented were obtained by XRF spectrometry. Also shown are the respective RE contents in post-archean Australian average shale (PAAS) (Taylor \& McLennan 1988). The RE contents in PAAS can be considered to represent those of the upper continental crust exposed to weathering and erosion. The median RE contents in the peat ashes from the different bedrock areas were roughly 16 times those in PAAS.

The chemical properties of peats depend on the compositions of the peat-forming plants, degree of humification and the mineral substances introduced from outside. The peat types of the now 
Table 2. Median RE contents and ranges ( $\mathrm{ppm}$ ) in peat ashes from rapakivi granite, granitic and archean gneiss areas, and in the post-archean Australian average shale (Taylor \& McLennan 1988). $N$ is the number of samples.

\begin{tabular}{|c|c|c|c|c|c|c|c|}
\hline & \multicolumn{6}{|c|}{ PEAT ASHES } & \multirow{3}{*}{$\begin{array}{c}\text { SHALE } \\
\text { RE } \\
\text { content in } \\
\text { post- } \\
\text { archean } \\
\text { shale }\end{array}$} \\
\hline & \multicolumn{2}{|c|}{$\begin{array}{l}\text { rapakivi granite } \\
(\mathrm{N}=152)\end{array}$} & \multicolumn{2}{|c|}{$\begin{array}{c}\text { granite } \\
(\mathrm{N}=190)\end{array}$} & \multicolumn{2}{|c|}{$\begin{array}{l}\text { archean gneiss } \\
\qquad(\mathrm{N}=57)\end{array}$} & \\
\hline & median & range & median & range & median & range & \\
\hline Y & 176 & $<20-3465$ & 50 & $<20-1303$ & 38 & $<20-288$ & 27 \\
\hline $\mathrm{La}$ & 200 & $<20-1268$ & 46 & $<20-1482$ & 100 & $<20-1176$ & 38 \\
\hline $\mathrm{Ce}$ & 506 & $<50-2598$ & 110 & $<50-3075$ & 220 & $<50-2278$ & 80 \\
\hline $\operatorname{Pr}$ & 40 & $<35-294$ & $<35$ & $<35-334$ & $<35$ & $<35-219$ & 8.9 \\
\hline $\mathrm{Nd}$ & 322 & $<35-1766$ & 56 & $<35-1523$ & 82 & $<35-976$ & 32 \\
\hline $\mathrm{Sm}$ & 38 & $<35-401$ & $<35$ & $<35-296$ & $<35$ & $<35-173$ & 5.6 \\
\hline
\end{tabular}

studied samples were mainly Carex (C) and Sphagnum (S) or their mixtures. In addition, some samples consisted of mixtures of $\mathrm{C}$ or $\mathrm{S}$ and Eriophorum, Equisetum and wood peat. The median ash content in $\mathrm{C}$ peats was $3.9 \%$, C,S peats $3.2 \%$ and $\mathrm{S}$ peats $1.8 \%$. Already Lounamaa (1956) showed that the Y contents in Finnish plants were highest in ferns, followed by lichens and mosses. Later, the RE contents in mosses and lichens gathered from different parts of Finland were determined (Erämetsä \& Yliruokanen 1971). Median contents of $\mathrm{Y}, \mathrm{La}, \mathrm{Ce}, \mathrm{Pr}, \mathrm{Nd}$ and $\mathrm{Sm}$ in the ashes of moss samples were $31,52,82,10,44$ and $11 \mathrm{ppm}$, respectively, and those in lichens were almost the same. As compared with the median RE contents in the peat samples from granite areas, a remarkable similarity can be observed.

The highest median contents were found in the samples from the mires where the bedrock consisted of rapakivi granite. This observation is in accordance with the relatively high RE contents of rapakivi granite in the same area (Koljonen \& Rosenberg 1974, Vaasjoki \& Rämö 1989). For instance, in Lapinjärvi the $\mathrm{La}, \mathrm{Ce}$ and $\mathrm{Nd}$ contents were reported to be 128,270 and $100 \mathrm{ppm}$, respectively (Koljonen \& Rosenberg 1974). The average RE contents in granites in Finland are clearly lower compared to those in rapakivi granites. This is also reflected to the RE contents in peat samples from the granite areas.

Recently, Y and La contents in till from different bedrock areas have been reported (Koljonen 1992). The average Y content in till from granite and archean gneiss areas was around $20 \mathrm{ppm}$. Hence the Y contents would have been expected to be similar in the peat samples from the respective areas. The median Y content in the peat ashes of samples from granite areas, however, was higher than in those from the archean gneiss areas. On the other hand, the La content in till from granite areas was about $30 \mathrm{ppm}$ and in archean gneiss $20 \mathrm{ppm}$. Therefore the other RE contents would have been expected to be higher in the samples collected from granite areas, but were found to be higher in the samples from archean gneiss areas. The discrepancy between the 
expected and observed contents is likely due to differences in sampling. The peat samples represent local variations whereas the RE contents in till represent regional averages. The median $\mathrm{Pr}$ and $\mathrm{Sm}$ contents in the samples from the granite and archean gneiss areas were below the detection limits of XRF spectrometry.

In Tables 3-5 the median contents and ranges of $\mathrm{Y}, \mathrm{La}, \mathrm{Ce}, \mathrm{Pr}, \mathrm{Nd}$ and $\mathrm{Sm}$ in peat ashes from each of the sampled mires are shown. The following observations concerning some individual mires can be made. The $\mathrm{Y}$ contents were especially high at Leppisuo and Haisevasuo mires in Luumäki, where the bedrock was of rapakivi granite. At granite areas extremely high RE contents were found at Rajasuo mire in Mäntsälä, where high uranium contents have also been detected (Yliruokanen 1980a). In the samples from Pitkästenjärvi mire nearby a similar phenomenon was discovered. Otherwise the median RE contents were close to those in PAAS. Among the mires sampled at archean gneiss area Vuonissuo mire in Lieksa exhibited the highest RE contents. The medians were comparatively high also at Säynäjäsuo mire in Kuusamo. Nothing definitive can be said about the Säynäjäsuo mire, though, since the number of samples was only 4 , and only one profile was analysed. No correlation between the peat type and the RE contents in peat nor the ash content, that would explain the high RE contents found in some of the mires, could be detected.

In general, the rare earth contents were higher in the basal peat layers. The tendency observed in the vertical distributions is in relation with the low mobilities of the rare earth elements. This is illustrated in Fig. 2 where the vertical distribution of four rare earths in three sampling sites from the different bedrock areas are shown. The RE contents both in peat ash and dry peat are presented since the ash contents are often higher in the samples from the basal layers.

The contents of all RE elements in 29 peat ash samples were determined by SSMS and the results were normalised to chondrite (Taylor \& McLennan 1988). The abundance patterns for some samples are shown in Figures 3 and 4 . In most of the samples analysed in the rapakivi granite area a negative Eu anomaly was discovered. For example in Fig. 3 a strong anomaly can be seen in samples $106 / 10 / 550$ and 107/2/400. Both of these samples were taken from the lowermost peat layer where the phenomenon is clearly pronounced as a result of reducing conditions. Near the surface the normalised Eu abundance becomes similar to the abundances of the other heavy rare earths. The same changes in Eu content vs. depth were detected in all the analysed samples from the rapakivi granite areas.

Normally, the RE abundance patterns in peat samples taken from rapakivi granite and granite areas resembled very much those of rapakivi granite and granite (Koljonen \& Rosenberg 1974). In the 8 patterns determined from three different mires situated at granite area the RE abundances were in general quite low. The heavy rare earths could not usually be detected by SSMS except in the samples from the Isosuo mire (105). The increase in RE content towards the basal layers can also be seen in the chondrite normalised abundance patterns. The RE contents were high in the samples from deepest sampling depths at Keihässuo (157) and Isosuo (105) mires, where the heavy RE element contents could also be determined (Fig. 4). In a sample taken near the surface at Keihässuo mire, however, the contents of the RE elements heavier than Nd could not be determined even by SSMS. The abundance patterns for the samples from archean gneiss areas were quite similar to those from granite areas. The patterns were determined for 6 samples from Sarvisuo (216) and Kaitalammensuo (260) mires. The Y, La, Ce, Pr and Nd contents were similar to those in sample $157 / 7 / 100$ (Fig. 4).

\section{CONCLUSIONS}

The median RE contents in the samples from rapakivi granite, granite and archean gneiss areas were 1-6 times the RE contents in PAAS. The 
Table 3. Median RE contents and ranges (ppm) in peat ashes from the mires situated at rapakivi granite areas as determined by XRF spectrometry.

\begin{tabular}{|c|c|c|c|c|c|c|}
\hline \multirow{2}{*}{ code, mire, municipality } & \multicolumn{2}{|l|}{$\mathrm{Y}$} & \multicolumn{2}{|l|}{$\mathrm{La}$} & \multicolumn{2}{|l|}{$\mathrm{Ce}$} \\
\hline & range & median & range & median & range & median \\
\hline 101 Pöllönsuo, Pyhtää & $31-361$ & 148 & $30-410$ & 128 & $78-964$ & 333 \\
\hline 102 Munasuo, Pyhtää & $<20-551$ & 120 & $<20-853$ & 97 & $43-1864$ & 246 \\
\hline 103 Vehkaojansuo, Sippola & $<20-513$ & 87 & $<20-1108$ & 94 & 39-2149 & 232 \\
\hline 104 Kajosuo, Vehkalahti & $22-368$ & 144 & $40-1021$ & 237 & $56-1812$ & 498 \\
\hline 106 Leppisuo, Luumäki & $<20-1011$ & 261 & $<20-1268$ & 241 & $51-2598$ & 452 \\
\hline 107 Haisevasuo, Luumäki & $<20-3465$ & 255 & $<20-1031$ & 222 & $90-2263$ & 493 \\
\hline 109 Haukkasuo, Valkeala & $40-397$ & 234 & $44-620$ & 356 & $129-1324$ & 789 \\
\hline
\end{tabular}

Table 4. Median RE contents and ranges ( $\mathrm{ppm}$ ) in peat ashes from the mires situated at granitic areas as determined by XRF spectrometry.

\begin{tabular}{|c|c|c|c|c|c|c|}
\hline \multirow{2}{*}{ code, mire, municipality } & \multicolumn{2}{|l|}{$\mathrm{Y}$} & \multicolumn{2}{|l|}{$\mathrm{La}$} & \multicolumn{2}{|l|}{$\mathrm{Ce}$} \\
\hline & range & median & range & median & range & median \\
\hline 105 Isosuo, Nastola & $21-264$ & 50 & $<20-456$ & 41 & $56-854$ & 136 \\
\hline 150 Piilonsuo, Janakkala & $22-142$ & 64 & $24-181$ & 59 & $<50-313$ & 85 \\
\hline 152 Kurkisuo, Hyvinkää & $<20-1303$ & 60 & $<20-495$ & 41 & $<50-829$ & 110 \\
\hline 155 Luutasuo, Loppi & $<20-586$ & 30 & $<20-873$ & 29 & $<50-1827$ & 92 \\
\hline 157 Keihässuo, Pyhäjärvi & $<20-569$ & 33 & $<20-666$ & 39 & $<50-1128$ & 91 \\
\hline 159 Lenninsuo, Loppi & $<20-90$ & 23 & $<20-60$ & $<20$ & $<50-187$ & 70 \\
\hline 163 Junninsuo, Mäntsälä & $34-215$ & 64 & $38-340$ & 59 & $98-643$ & 146 \\
\hline 164 Isosuo, Mäntsälä & $37-283$ & 65 & $34-323$ & 79 & $98-560$ & 158 \\
\hline 167 Toivike, Pyhäjärvi & $<20-197$ & 31 & $<20-142$ & 35 & $<50-358$ & 67 \\
\hline 171 Mustasuo, Hausjärvi & $<20-192$ & 35 & $<20-294$ & 33 & $<50-521$ & 103 \\
\hline 172 Ritassaarensuo, Hyvinkää & $<20-92$ & 45 & $<20-100$ & 32 & $60-269$ & 78 \\
\hline 175 Rajasuo, Mäntsälä & $96-856$ & 560 & $114-1482$ & 843 & $217-3075$ & 1552 \\
\hline 176 Pitkästenjärvi, Mäntsälä & $23-309$ & 109 & $33-368$ & 118 & $71-679$ & 271 \\
\hline
\end{tabular}

Table 5. Median RE contents and ranges (ppm) in peat ashes from the mires situated at archean gneiss areas as determined by XRF spectrometry.

\begin{tabular}{|c|c|c|c|c|c|c|}
\hline \multirow{2}{*}{ code, mire, municipality } & \multicolumn{2}{|l|}{$\mathrm{Y}$} & \multicolumn{2}{|c|}{$\mathrm{La}$} & \multicolumn{2}{|l|}{$\mathrm{Ce}$} \\
\hline & range & median & range & median & range & median \\
\hline 215Rimpisuo, Lieksa & $<20-179$ & 55 & $61-370$ & 127 & $106-772$ & 292 \\
\hline 216 Sarvisuo, Kuhmo & $<20-95$ & $<20$ & $<20-349$ & 65 & $<50-726$ & 108 \\
\hline 260 Kaitalammensuo, Eno & $<20-35$ & $<20$ & $<20-105$ & $<20$ & $<50-221$ & 65 \\
\hline 261 Vuonissuo, Lieksa & $<20-288$ & 87 & $37-1176$ & 215 & $107-2278$ & 500 \\
\hline 303 Säynäjäsuo, Kuusamo & $64-137$ & 91 & $159-544$ & 337 & $341-1108$ & 735 \\
\hline 306 Pötkönsuo, Kuusamo & $<20-116$ & 62 & $26-304$ & 118 & $89-586$ & 268 \\
\hline
\end{tabular}




\begin{tabular}{|c|c|c|c|c|c|c|c|}
\hline \multicolumn{2}{|l|}{$\operatorname{Pr}$} & \multicolumn{2}{|l|}{$\mathrm{Nd}$} & \multicolumn{2}{|c|}{$\mathrm{Sm}$} & \multirow{2}{*}{$\begin{array}{c}\text { number of } \\
\text { drilling } \\
\text { holes }\end{array}$} & \multirow{2}{*}{$\begin{array}{c}\text { number } \\
\text { of } \\
\text { samples }\end{array}$} \\
\hline range & median & range & median & range & median & & \\
\hline$<35-72$ & $<35$ & $34-444$ & 177 & $<35-91$ & $<35$ & 4 & 13 \\
\hline$<35-178$ & $<35$ & $<35-851$ & 111 & $<35-154$ & $<35$ & 4 & 20 \\
\hline$<35-183$ & $<35$ & $<35-916$ & 98 & $<35-170$ & $<35$ & 7 & 28 \\
\hline$<35-165$ & 50 & $51-708$ & 242 & $<35-125$ & 37 & 6 & 18 \\
\hline$<35-294$ & 53 & $36-1292$ & 279 & $<35-272$ & 53 & 9 & 41 \\
\hline$<35-263$ & 47 & $<35-1766$ & 168 & $<35-401$ & 52 & 7 & 27 \\
\hline$<35-138$ & 62 & $55-583$ & 404 & $<35-139$ & 52 & 1 & 5 \\
\hline
\end{tabular}

\begin{tabular}{|c|c|c|c|c|c|c|c|}
\hline \multicolumn{2}{|l|}{$\operatorname{Pr}$} & \multicolumn{2}{|c|}{$\mathrm{Nd}$} & \multicolumn{2}{|c|}{$\mathrm{Sm}$} & \multirow{2}{*}{$\begin{array}{c}\text { number of } \\
\text { drilling } \\
\text { holes }\end{array}$} & \multirow{2}{*}{$\begin{array}{c}\text { number } \\
\text { of } \\
\text { samples }\end{array}$} \\
\hline range & median & range & median & range & median & & \\
\hline$<35-91$ & $<35$ & $<35-433$ & 62 & $<35-80$ & $<35$ & 4 & 19 \\
\hline$<35-37$ & $<35$ & $<35-168$ & 75 & $<35$ & $<35$ & 4 & 14 \\
\hline$<35-166$ & $<35$ & $<35-865$ & 54 & $<35-209$ & $<35$ & 4 & 18 \\
\hline$<35-201$ & $<35$ & $<35-912$ & $<35$ & $<35-173$ & $<35$ & 2 & 13 \\
\hline$<35-170$ & $<35$ & $<35-825$ & 47 & $<35-156$ & $<35$ & 4 & 19 \\
\hline$<35$ & $<35$ & $<35-74$ & $<35$ & $<35$ & $<35$ & 4 & 14 \\
\hline$<35-79$ & $<35$ & $42-350$ & 67 & $<35-65$ & $<35$ & 5 & 19 \\
\hline$<35-64$ & $<35$ & $37-336$ & 72 & $<35-60$ & $<35$ & 4 & 13 \\
\hline$<35-47$ & $<35$ & $<35-156$ & $<35$ & $<35-41$ & $<35$ & 3 & 19 \\
\hline$<35-50$ & $<35$ & $<35-311$ & 40 & $<35-78$ & $<35$ & 3 & 17 \\
\hline$<35$ & $<35$ & $<35-100$ & $<35$. & $<35$ & $<35$ & 2 & 7 \\
\hline$<35-334$ & 146 & $96-1523$ & 779 & $40-292$ & 146 & 3 & 9 \\
\hline$<35-83$ & $<35$ & $<35-398$ & 139 & $<35-74$ & $<35$ & 3 & 9 \\
\hline
\end{tabular}

\begin{tabular}{|c|c|c|c|c|c|c|c|}
\hline \multicolumn{2}{|l|}{$\mathrm{Pr}$} & \multicolumn{2}{|c|}{$\mathrm{Nd}$} & \multicolumn{2}{|c|}{$\mathrm{Sm}$} & \multirow{2}{*}{$\begin{array}{c}\text { number of } \\
\text { drilling } \\
\text { holes }\end{array}$} & \multirow{2}{*}{$\begin{array}{c}\text { number } \\
\text { of } \\
\text { samples }\end{array}$} \\
\hline range & median & range & median & range & median & & \\
\hline$<35-96$ & $<35$ & $66-386$ & 143 & $<35-66$ & $<35$ & 3 & 10 \\
\hline$<35-45$ & $<35$ & $<35-241$ & 58 & $<35$ & $<35$ & 4 & 12 \\
\hline$<35$ & $<35$ & $<35-82$ & $<35$ & $<35$ & $<35$ & 3 & 14 \\
\hline$<35-219$ & $<35$ & $48-976$ & 201 & $<35-173$ & $<35$ & 4 & 9 \\
\hline$<35-90$ & $<35$ & $122-426$ & 301 & $<35-72$ & $<35$ & 1 & 4 \\
\hline$<35$ & $<35$ & $47-219$ & 110 & $<35-36$ & $<35$ & 3 & 8 \\
\hline
\end{tabular}




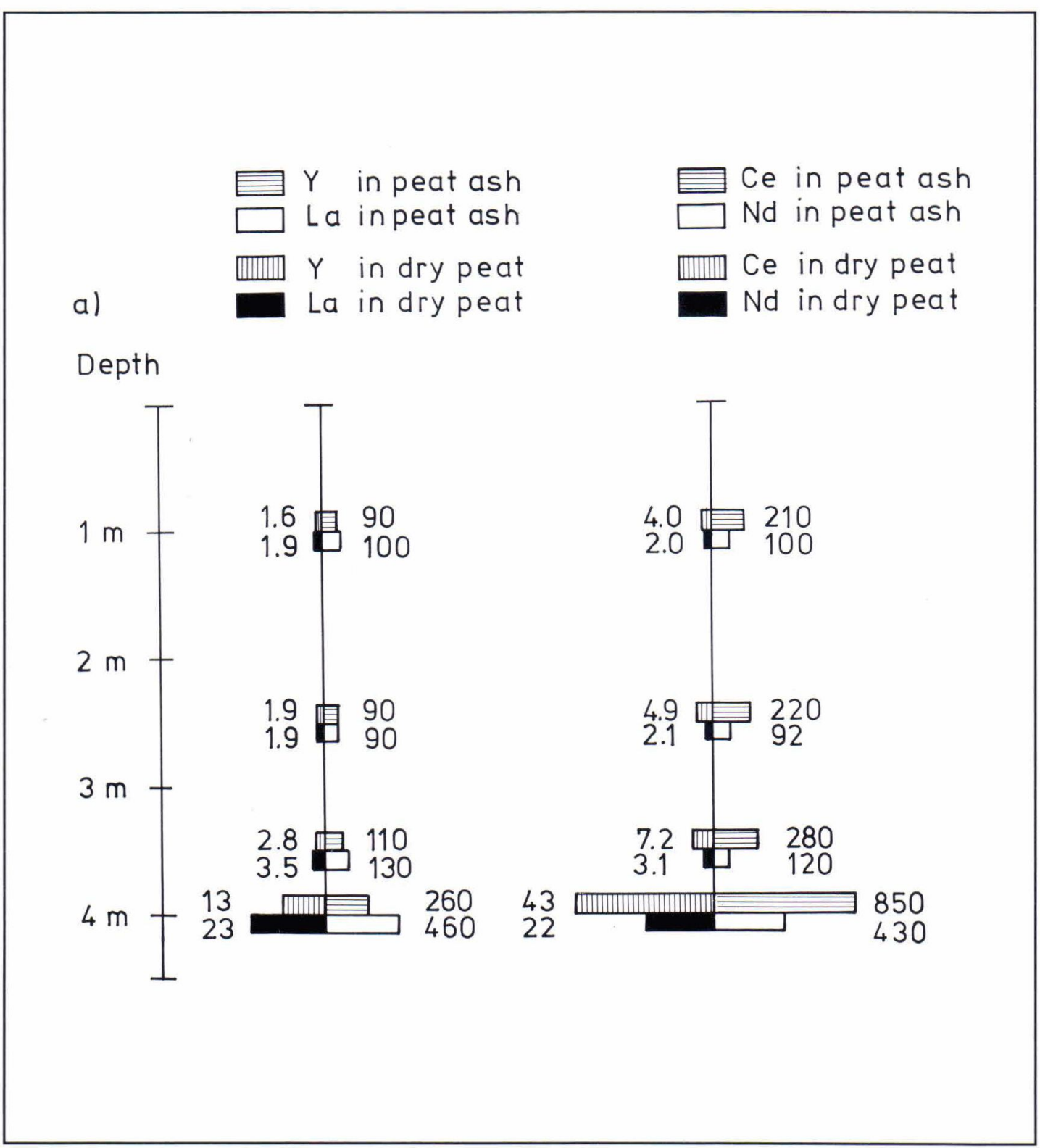

Figure 2. Vertical distribution of $\mathrm{Y}, \mathrm{La}, \mathrm{Ce}$ and $\mathrm{Nd}$ contents (ppm) in peat ash and dry peat in three mires.

a) Isosuo in Nastola (105). Bedrock consists of granite; peat in basal layers is Carex and Sphagnum in the two samples from the surface layers.

b) Säynäjäsuo in Kuusamo (303). Bedrock archean gneiss; peat Carex.

c) Leppisuo in Luumäki (106). Bedrock rapakivi granite; peat Carex., 

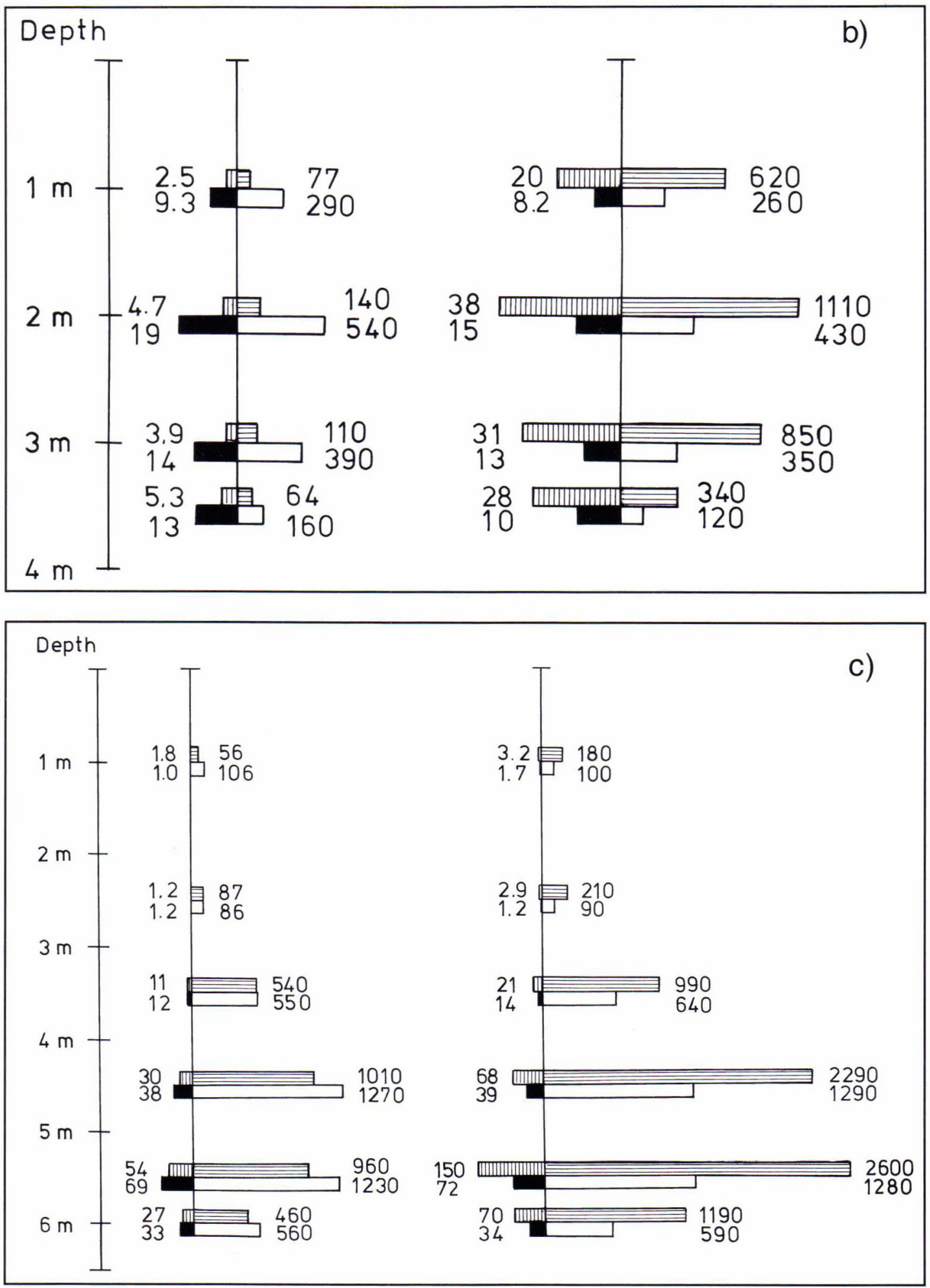


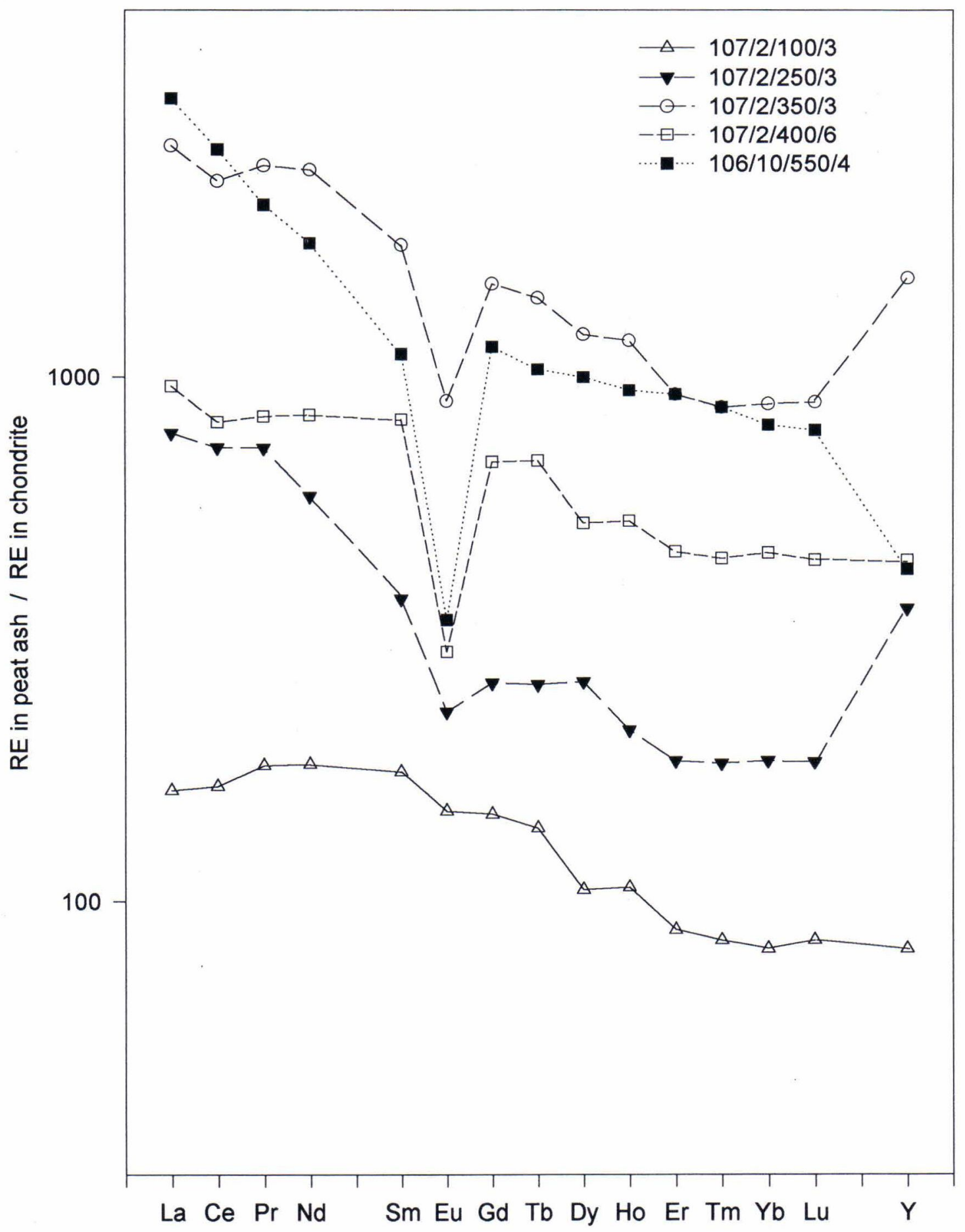

Figure 3. Chondrite normalised RE abundances in some mires where the bedrock consists of rapakivi granite. The code of the mire, the drilling hole number, the sampling depth $(\mathrm{cm})$ and the degree of $v$. Post humification (1-10) are given in the legend. 


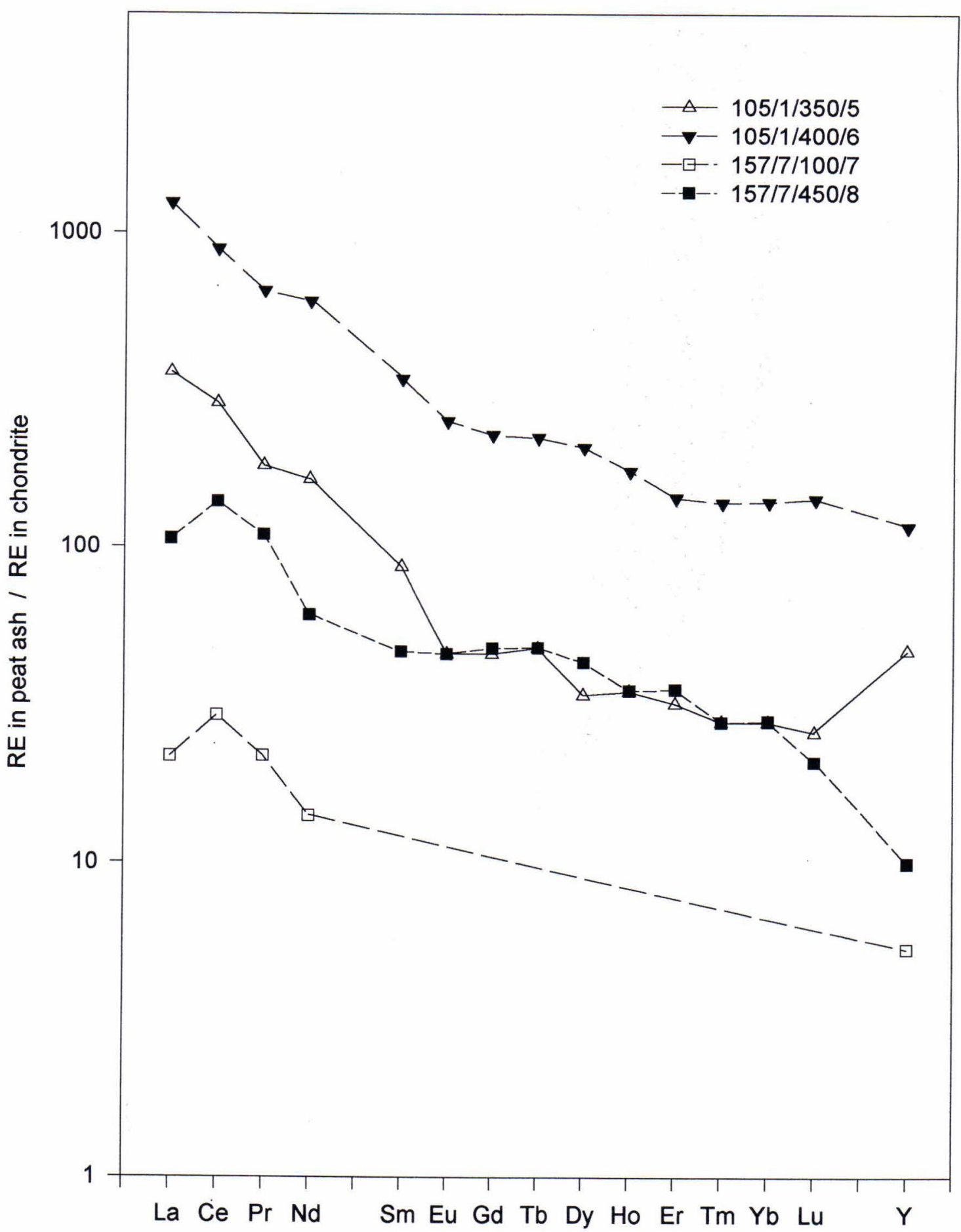

Figure 4. Chondrite normalised RE abundances in some mires where the bedrock consists of granite. Legends as in Fig. 3. 
highest RE contents were found in peat samples from rapakivi granite areas whereas in the samples form granite and archean gneiss areas the medians were of the same magnitude. A strong negative $\mathrm{Eu}$ anomaly was discovered in the samples from

\section{REFERENCES}

Erämetsä, O. and Yliruokanen, I., 1971. The rare earths in lichens and mosses. Suomen Kemistilehti B44, 121128.

Henderson, P., (ed.) 1984. Developments in geochemistry vol.2. Rare earth geochemistry. Elsevier, Amsterdam. $510 \mathrm{pp}$.

Koljonen, T., (ed.) 1992. The geochemical atlas of Finland, part 2: till. Geological Survey of Finland, Espoo. 218 pp.

Koljonen, T. and Rosenberg, R., 1974. Rare earth elements in granitic rocks. Lithos 7, 249-261.

Lounamaa, J., 1956. Trace elements in plants growing wild on different rocks in Finland. Annales of the Botanic Society, "Vanamo" 29, 18.

Markert, B. and Thornton, I., 1990. Multi-element analysis of an English peat bog soil. Water, Air, and Soil Pollution 49, 113-123.

Minkkinen, P. and Yliruokanen, I., 1978. The arsenic distribution in Finnish peat bogs. Kemia-Kemi 5, 331335.

Nieminen, K. and Yliruokanen, I., 1974. Trace element analysis of granitic and radioactive rocks by spark source mass spectrometry with electrical detection. rapakivi granite areas. In general the RE contents were highest at the basal peat layers.

ACKNOWLEDGEMENT: Neste Oy Foundation is thanked for financial support during the sampling period.

Bulletin of the Geological Society of Finland 46, 167 176.

Read, D. and Hooker, P.J., 1989. The speciation of uranium and thorium at the Broubster natural analogue site, Caithness, Scotland. Materials Research Society, Symposium Proceedings 127, 763-770.

Taylor, S.R. and McLennan, S.M., 1988. The significance of the rare earths in geochemistry and cosmochemistry. In Gschneidner, K.A. Jr. and Eyring, L. (ed.): Handbook on the physics and chemistry of rare earths, vol.11. Elsevier, Amsterdam. 485-578.

Vaasjoki, M. and Rämö, T., 1989. The Wiborg rapakivi batholith and associated rocks in south-eastern Finland. Excursion A2, IGCP Projects 217 and 247. Geological Survey Finland, Opas-Guide 30. 32 pp.

Virtanen, K., 1993. Geology of the Pitkäslähde spring, Western Finland, and the enrichment of elements from groundwater to peat. Bulletin of the Geological Society of Finland 65, 41-48.

Yliruokanen, I., 1980a. The occurrence of uranium in some Finnish peat bogs. Kemia-Kemi 7, 213-217.

Yliruokanen, I., 1980b. The occurrence of zinc in some Finnish peat bogs. Kemia-Kemi 7, 447-450.

Yliruokanen, I., 1981. The occurrence of copper and nickel in some Finnish peat bogs. Kemia-Kemi 8, 229-233. 